УДК: 159.942 : $796.3: 355.5-615.8: 616-001$

Оксана Юденко

кандидат педагогічних наук,

Національний університет фізичного виховання і спорту України

ORCID ID 0000-0002-8485-7794

Василь Білошицький

Навчально-науковий інститут фізичної культури та спортивно-оздоровчих технологій Національного університету оборони України імені Івана Черняховського

ORCID ID 0000-0001-6083-2579

Сергій Бойченко

Національний університет фізичного виховання і спорту України

ORCID ID 0000-0002-1196-3852

Генадій Галашевський

Навчально-науковий інститут фізичної культури та спортивно-оздоровчих технологій Національного університету оборони України імені Івана Черняховського

ORCID ID 0000-0001-7661-6213

DOI: $10.33099 / 2617-1775 / 2021-01 / 381-392$

\title{
КОРЕКЦІЯ СТРЕСОСТІЙКОСТІ ЗАСОБАМИ СПОРТИВНИХ ІГОРУ ВІЙСЬКОВСЛУЖБОВЦІВ ІЗ НАСЛІДКАМИ БОЙОВОЇ ТРАВМИ
}

У статті авторами розглянуто сучасні аспекти та питання, які викликають гальмування розвитку системи надання якісних фізкультурно-спортивних послуг учасникам бойових дій та членам їх родин з позииій сьогодення; визначено, питанням реабілітації та корекційно-відновлювального впливу на учасників бойових дій, які повертаються до життя в мирних умовах присвячено достатню кількість досліджень, але вони практично не висвітлюють особливості застосування засобів фізкультурно-спортивної реабілітації на психофізичний стан військових із наслідками бойової травми та ефективної системи реалізації фізкультурно-спортивних послуг з метою подолання наслідків впливу військового конфлікту на військових, щуо приймали участь у бойових діях на Сході Украйни та членів їх родин; подано узагальнені підходи до проявів стресостійкості, особливостей корекції иьього стану організму; подано результати дослідження здійсненого протягом 2019-2020 рр. які характеризують особливості зміни динаміки середніх показників прояву депресивного стану (за PHQ-9), ступеню прояву ПТСР та задоволеністю якістю життя за технологією «Колесо життєвого балансу» - отримані дані свідчать про позитивний кількісний та якісний вплив на означені показники як комплексних складових стресостійкості особистості в сучасному динамічному суспільстві та дозволяють стверджувати щзо адаптивний регбі та футбол є сучасними трендовими фізкультурно-спортивними послугами для учасників бойових дій та членів їх родин, які дозволять позитивним чином вплинути на рівень соціальної адаптації військовослужбовщчв із наслідками бойової травми, підвищити загальний рівень опору стресу.

Ключові слова: футбол, регбі, фізкультурно-спортивна реабілітація, бойовий стрес, корекиійно-реабілітаційний вплив, учасники АТО/OОС.

Постановка проблеми. В сучасній Україні в умовах військового конфлікту, який i досі триває на Сході нашої держави із систематичним збільшенням кількості осіб, які повертаються до життя на мірній території після участі в ООС, часто отримавши бойові травми важкого та середнього ступеню, що пов’язні на лише із дисфункціями в психічній та соціальній сферах, а 
призводять до каліцтва та інвалідізації внаслідок участі у бойових діях актуальним залишається питання корекції рівня стресостійкості цих військових та членів їх родин, ефективного подолання наслідків бойової травми та повернення їх до соціального, побутового та професійного життя.

Актуальність роботи полягає в тому, що із 2014 р. коли проти України було розпочато військові дії на Сході країни кількість осіб, які потребують якісного, ефективного, своєчасного корекційно-реабілітаційного втручання постійно зростає. На сьогодні кількість осіб офіційно зареєстрованих як учасник бойових дій сягнула вже понад 500000 осіб, але при цьому лише тільки понад 40000 травмованих військових із різними наслідками бойової травми (БТ) отримали необхідні реабілітаційні та фізкультурно-спортивні послуги (РП та ФСП). Означена ситуація обумовлена низкою факторів серед яких: 1) комплексна система надання реабілітаційних та фізкультурно-спортивних послуг в Україні лише формується (тільки 23 серпня 2020 р. підписано Указ Президента України № 342/2020 та затверджено «Національну Стратегію розвитку системи фізкультурно-спортивної реабілітації ветеранів війни та членів їх сімей, сімей загиблих (померлих) ветеранів війни»); 2) практично відсутні фахівці, які після завершення навчання у закладів вищої освіти готові без додаткового спеціально-спрямованого підвищення кваліфікації вирішувати професійні завдання із учасниками бойових дій в зоні АТО/ООС, які мають різні ступені ураження організму та інвалідність внаслідок бойових дій. Також у своїх роботах 2018-2020 pp. О.В. Юденко і Н.М. Крушинська [2] констатують, що актуальними проблемами ефективної системи реабілітації в нашій країні $є$ : 1) щорічний перегляд групи (особливо для осіб, які мають явні каліцтва ампутації; втрата зору); 2) погане, несвоєчасне, довготривале забезпечення протезами (i спортивними в тому числі), візками, милицями тощо; 3) віддаленість спеціалізованих установ від замовників та отримувачів РП та ФСП; 4) розпорошеність фахової діяльності між відомствами та Міністерствами; 5) неякісне інформування про ФСП відсутність централізованої всеукраїнської бази реєстрації (яка повинна містити, на нашу думку, розділи «Особи, які потребують отримання послуги» та «Фахівці, які надають послуги»), для створення умов максимальної мобільності у задоволенні потреб у відновленні стану здоров'я, руховій активності та соціальній адаптації військових із наслідками БТ та членів їх родин; 6) корупційні схеми; 7) дуже довге отримання документів учасника бойових дій, особливо тих, хто отримав каліцтва та знаходиться на відповідному лікуванні та реабілітації.

Слід зазначити що різні аспекти реабілітації та адаптації учасників бойових дій та членів їх родин досліджував такий вчений як Ю.Л. Бриндіков [3].

О.В. Богомолець, І.Я. Пінчук та А.К. Ладик-Бризгалова звертають увагу фахівців різних галузей на необхідність дослідження поширеності та структури посттравматичних психічних порушень в учасників бойових дій.

Грунтовно питання військової психології представлено в наукових працях В.В. Ягупова [17] та різні аспекти психології бойової психічної травми 
висвітлено у дослідженнях О.А. Блінова. При цьому окремі аспекти впровадження комплексних програм ФСР; питання готовності фахівців 017 ФКіС до вирішення професійних завдань із військовослужбовцями із наслідками БТ висвітлено в роботах О.В. Юденко із співавторами Д.С. Бабенко, А.С. Білоус, С.В. Бойченко, І.В. Гевчук, С.М. Жембровський, Н.М. Крушинська, О.О. Курбасов, А.А. Мартиросян, О.В. Петрачков, В.В. Правдивий, А.О. Тесленко, Я.М. Фролов, С.О. Шапіро, В.В. Шевченко $[2 ; 4 ; 5 ; 7 ; 11 ; 13]$.

Питання психоемоційних станів комбантанів досліджували такі фахівці як А.А. Булан (2015); I. Гайда, Б.Б. Жупан, М. Бадюк та I. Сушко (2016; 2018); Ю.О. Гріненко (2016); О.І. Донець та Д.О. Шміголь (2017); Г.В. Іванцова (2008); О.М. Кокун, Н.А. Агаєв, І.О. Пішко, Н.С. Лозінська та В.В. Остапчук (2017); І.М. Гулієв (2004); О.В. Корчагина (2008); Я.В. Кравченко (2019); Дж. Креймер (2016); I.А. Литвин (2016); Б. Ткач (2016); I.I. Черненко (2017); Т.В. Рогачова, Г.В. Залевський, Т.Е. Левицька (2015); С.Л. Панасенко (2009); О.О. Буряк, М.І. Гіневський, Г.Л. Катеруша (2015) та інші.

Питанням фізичної медицини та реабілітації військовослужбовців, відновлення їх фізичного, психологічного та соціального здоров'я, підвищення рівня стресостійкості та ефективного подолання наслідків бойової травми присвячено роботи закордонних фахівців: Ph.J. Belmont, B.J. McCriskin \& R.N. Sieg [19]; J. Rich, D.E. Dean \& R.H. Powers [20]; J.J. Knapik, S.B. Jones \& S. Darakjy [21]; R. Marin [22]; B.D. Owens, J.F. Kragh \& J.C. Wenke [23]; Kathleen E. Yancosek I., Tanja Roy, Mary Erickson [25]; Mary Beth MacLean, Linda Van Til, James M. Thompson, Jill Sweet, Alain Poirier, Kerry Sudom, David J. Pedlar [24]; S. Truffaut, M. Thomas-Pohl, L. Borrini, D. Rogez, J. Facione, E. Lapeyre [26]; C.M. Williams, T. Williams, S.Sonnenberg, A. Blank, J. Tallbot [27];та інші.

О.В. Юденко, Н.М. Крушинська, С.М. Жембровський [2; 13] у своїх дослідженнях підкреслюють думку про те, що об'єктами професійної діяльності фахівців із фізкультурно-спортивної реабілітації (ФСР), які потребують реабілітаційного впливу з метою подолання наслідків БТ з точки зору фізичного, психічного та соціального здоров'я особистості $\epsilon$ військовослужбовці - учасники АТО/ООС та члени їх родин; цивільні особи, які зазнали поранень, контузій або каліцтв; особи (військові та цивільні), які перебували в полоні; особи, які отримали інвалідність через стреси або переховування від обстрілів; медичні працівники та волонтери, які надають допомогу учасникам бойових дій в Україні та членам їх родин, родинам загиблих військовослужбовців.

Нажаль, і доступних інформаційних джерелах практично відсутня інформація щодо впливу занять фізкультурно-спортивною реабілітацією на показники соціальної адаптації, психо-фізичного стану, на ступінь прояву фізичної та розумової працездатності військових із наслідками БТ, на рівень їх стресостійкості та окремі їі складо,ві.

Методологія дослідження. Робота виконана в межах тем «Розвиток військово-прикладних навичок та стресостійкості військовослужбовців 
засобами кросфіту» (Шифр: «Наполегливість») i НОУО імені Івана Черняховського 2021-2022 pр. та Зведеного плану НДР НУФВСУ 2021-2025 pp. за темою «Теоретико-методологічні засади розвитку професійного, неолімпійського та адаптивного спорту в Україні в умовах реформування галузі фізичної культури і спорту» (протокол Вченої ради № 2 від 29.10.2020).

Мета роботи: оцінка ступеню прояву стресостійкості у військових із наслідками БТ та його корекція засобами спортивних ігор. У відповідності до мети роботи визначено такі завдання дослідження: 1) здійснити ретроспективний аналіз та узагальнення інформації щодо особливостей корекції стресостійкості військовослужбовців із наслідками бойової травми засобами спортивних ігор; 2) експериментально перевірити ефективність застосування спортивних ігор (адаптивного футболу та регбі) в системі фізкультурно-спортивної реабілітації військових із наслідками БТ та впливу їх засобів на рівень стресостійкості та соціальної адаптації.

Для вирішення означених нами завдань дослідження використовували такі методи дослідження як: а) аналіз та узагальнення науково-методичних та електронних інформаційних джерел за проблематикою дослідження; б) експрес-оцінювання ПТСР; в) самооцінка здоров'я у військових «PHQ-9» (самооцінка депресивного стану); г) сучасна педагогічна SMART-технологія «Колесо життєвого балансу»; д) методи математичної статистики (критерій Стьюдента).

Виклад основного матеріалу дослідження. В нашому дослідженні ми використовували поняття «стресостійкості» яке тлумачать як «комплекс особистісних якостей, що дозволяють переносити значні інтелектуальні, вольові та емоційні навантаження без особливих шкідливих наслідків для власного здоров'я, оточуючих і своєї професійної діяльності» [3; 8; 17].

Узагальнюючи дані літератури $[1 ; 3 ; 7-12 ; 15 ; 16]$ можна зробити висновок про те, що: 1) стресостійкість дає можливість уникнути стресу, шляхом перегляду ставлення до ситуації; 2) позитивна функція - прояв захистної реакції організму від негативного впливу на здоров'я людини; 3) стресостійка людина, незалежно від зовнішніх умов, може виконувати поставлене завдання (без відволікання на шум, сторонні питання, заздрість колег, сімейні проблеми тощо); це завжди особистість, яку виділяється на фоні інших людей (спокійна, впевнена собі, самодостатня, людина-лідер); з будьякої ситуації вона здатна спокійно та зважено знайти вихід; 4) факторами, які сприяють ефективному протистоянню стресу є ефективне планування часу; схильність до оптимізму; уміння розслаблятися; розуміння своїх емоцій; самоконтроль і позитивний настрій.

О. А. Орловська [10, с. 102] спираючись на дослідження Ю.Ф. Акименко та T.I. Сила [1, с. 9-10] констатує, що за даними різних країн де вивчались питання впливу бойової травми на стан комбатантів «приблизно 25-30\% військовослужбовців, які брали участь у бойових діях, переживають хронічні посттравматичні стани (ПТСР), що викликані впливом стресових факторів.

А.П. Чапляк, О.П. Романів, Б.А. Надь [16] та О.Г. Сироп'ятов [14] виокремлюють 2 провідні клінічні варіанти розладів адаптації які мають 
відмінності особливостями домінуючої симптоматики (афективний та поведінковий варіанти) та грунтовно охарактеризували в своїх наукових працях.

Т.М. Титаренко [15] наголошує на тому, що «ефективність відновлення психологічного здоров'я забезпечується такими векторами реабілітаційної роботи як спрямованість на досягнення стійкого самоприйняття, відновлення самоефективності, здатності до ціннісно-смислового оновлення та підвищення рівня комунікативної компетентності». При цьому авторка акцентує увагу на тому, що «змістовими мішенями реабілітаційних впливів слід вважати активізацію готовності особистості: а) до змін у ставленні до себе, самоідентифікації; б) до змін у сфері значущих стосунків, освоєнні нової комунікативної території; в) до змін у сенсорному сприйнятті оточуючого середовища, наповненні власного повсякдення новими смислами, а майбутнього - новими перспективами» [15].

Бойовий стрес, як психотравмуюча ситуація та реакція організму на його вплив

\begin{tabular}{|c|c|c|}
\hline $\begin{array}{c}\text { фізичні } \\
\text { реакції } \\
\text { (безсоння, } \\
\text { постійна втома; } \\
\text { проблеми зі } \\
\text { шлунком та } \\
\text { вживанням їжі; } \\
\text { головний біль та } \\
\text { пітливість при думці } \\
\text { про війну; швидке } \\
\text { сепгебиття i }\end{array}$ & & $\begin{array}{c}\text { емоційні реакції } \\
\text { (погані сни, кошмари; часті негативні } \\
\text { спогади про війну; злість, ненависть; } \\
\text { відчуття безпорадності, страху, } \\
\text { нервування; відчуття суму, самотності, } \\
\text { непотрібності; відчуття збудження, } \\
\text { схвильованості; відчуття шоку, оніміння, } \\
\text { неможливості відчувати позитивні емоції; } \\
\text { легко погіршуваний настрій; почуття } \\
\text { провини, сорому, самосуду; почуття } \\
\text { безнадії щодо майбутнього) }\end{array}$ \\
\hline
\end{tabular}

О.А. Орловська [10, с. 104] підкреслює, що «психологічні чинники в процесі адаптації учасників бойових дій та їх сімей до цивільного життя посідають ключове місце, оскільки ці аспекти впливають на психологічний клімат сім'ї, характер їх взаємовідносин. Для учасника бойових дій сім'я $€$ потужним ресурсом підтримки, а розроблені рекомендації для членів сім’ї можуть позитивно вплинути на перебіг процесу адаптації.

Також Т.М. Титаренко [15] зазначає, що «основною умовою збереження психологічного здоров'я $\epsilon$ готовність особистості до творчого конструювання власного життя, а засобом його відновлення $\epsilon$ соціально-психологічна реабілітація як комплексний процес активізації життєтворення та підвищення суб'єктивного благополуччя». Ми можемо додати також, що ефективним засобом відновлення як фізичного так і психологічного здоров'я учасників бойових дій $\epsilon$ фізкультурно-спортивна реабілітація (важлива складова сучасних фізкультурно-спортивних послуг для військовослужбовців - учасників бойових дій та членів їх родин), яка у відповідності до Закону України «Про фізичну культуру і спорт» (ст. 1) [6] слід розглядати як «система заходів, розроблених із застосуванням фізичних вправ для відновлення здоров'я особи та спрямованих на відновлення і компенсацію за допомогою занять фізичною культурою і 
спортом функціональних можливостей іï організму для поліпшення фізичного i психологічного стану».

О.А. Орловська [10, с. 102] розглядає «адаптацію учасників бойових дій як процес пристосування особистості до нових умов соціального середовища через оволодіння нормами поведінки, пристосування до вимог суспільства: маємо на увазі узгодження розбіжностей між вимогами і очікуваннями соціуму стосовно людини та іiі реальною поведінкою, і між можливостями людини та реаліями соціального середовища, в якому вона перебуває». Дослідниця вважає, що «в процесі адаптації до нових умов життя учасники бойових дій можуть переживати психологічні труднощі, які обумовлені кардинальними змінами діяльності, що викликає стрес» [10, с. 102].

В нашому дослідженні протягом 2019-2020 років приймало участь 99 осіб - учасники бойових дій в Україні: серед них 42 військових займаються адаптивним регбі, 57 осіб займаються адаптивним футболом в секція ФСР. Аналіз вікових показників засвідчив, що серед військових із наслідками БТ, які займаються адаптивним регбі середній вік в групі становить $35,50 \pm 5,71$ років, а у тих хто займається адаптивним футболом він дорівнював $38,84 \pm 51,78$ років.

Відповіді отримані під час опитування засвідчили, що термін травматизації у військовослужбовців із наслідками БТ у учасників АТО/ООС, які займаються регбі становить 23,88 $\pm 8,93$ місяців (1,99 роки); тих, хто

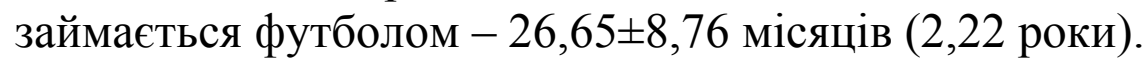

В нашому досліджені ми розглядаємо прояви ПТСР, депресивні прояви та задоволеність якістю життя, як складові стресостійкості людини. Особливо це важливо для військовослужбовців із наслідками бойової травми, які повертаються з зони АТО/ООС до життя в умовах мирного суспільства.

Табличя 1

Середні показники прояву ступеню ПТРС та депресивного стану у військовослужбовців із наслідками БТ, які займаються спортивними іграми (в балах)

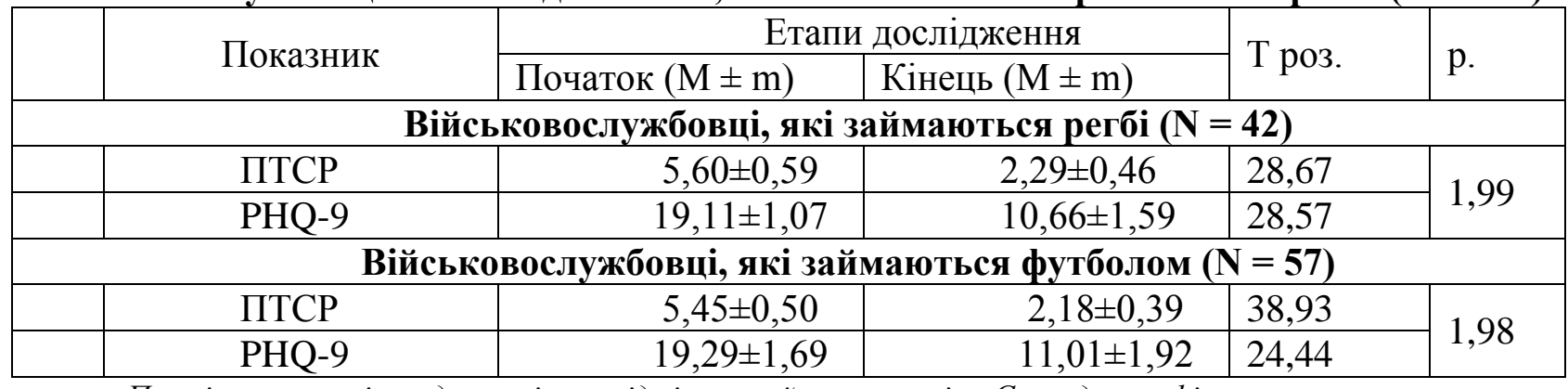

Примітка: наявність достовірних відмінностей за критерієм Стьюденту фіксується при $t$ роз. $>t$ гр.

Дослідження психо-фізичного стану у військовослужбовців із дисфункціями внаслідок бойової травми (за наявністю ПТСР та депресивних станів) дозволило нам констатувати, що зменшення психічного та психоемоційного напруження, виявило кількісні та якісні зміни в динаміці отриманих нами на протязі дослідження результатів. Отже, військовослужбовиі, які отримують ФСП в секиіях з футболу: на початку дослідження середні значення за показником ПТСР дорівнював 5,45 $\pm 0,5$ балів (надмірний рівень), на

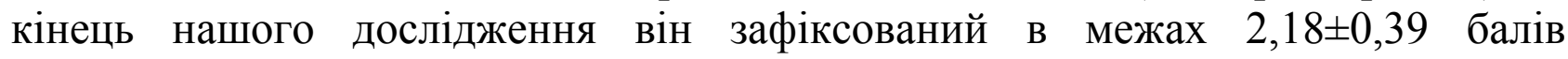


(оптимальний рівень; за критерієм Стьюдента зафіксовано достовірні відмінності; табл. 2); ветерани бойових дій, які займаються ФСР в секиіях 3 регб $i$ : на початку дослідження середні значення за показником ПТСР

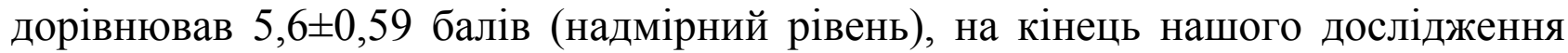

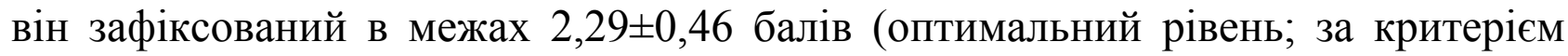
Стьюдента зафіксовано достовірні відмінності). Отже, за показником проявів ПТСР виявлено, якісні та кількісні достовірні зміни, які дозволяють визнати регбі та футбол ефективним засобом ФСР у військовослужбовців I-II зрілого віку із наслідками впливу БТ.

За шкалою самооцінки депресії (PHQ-9) у військовослужбовців, які займаються регбі протягом дослідження дорівнює $(19,11 \pm 1,07$ балів (крайня

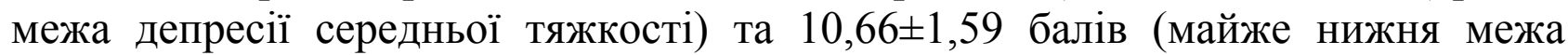
депресії помірної тяжкості); протягом дослідження показник зменшився на 44,22\%); у військових, які займаються футболом вони зафіксовані в межах

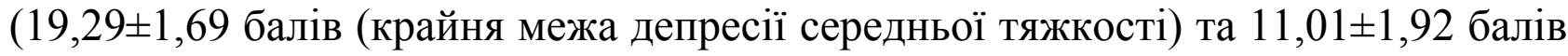
(депресія помірної тяжкості; протягом дослідження показник зменшився на $42,92 \%)$ ). За всіма показниками в межах кожної групи нами в ході дослідження виявлено достовірні відмінності за критерієм Стьюденту (дані подано в табл. 1).

Середні показники критеріїв задоволеності якістю життя в методиці

Таблиия 2 «Колесо життєвого балансу» у військовослужбовців - учасників АТО/ООС із наслідками бойової травми, які займаються спортивними іграми (в балах)

\begin{tabular}{|c|c|c|c|c|}
\hline \multirow[t]{2}{*}{ Показник } & \multicolumn{2}{|c|}{ Етапи дослідження } & \multirow{2}{*}{ Т роз. } & \multirow{2}{*}{ p. } \\
\hline & Початок $(\mathrm{M} \pm \mathrm{m})$ & Кінець $(\mathrm{M} \pm \mathrm{m})$ & & \\
\hline \multicolumn{5}{|c|}{ Військовослужбовці, які займаються регбі $(\mathrm{N}=42)$} \\
\hline Здоров’я і спорт & $2,36 \pm 0,59$ & $4,57 \pm 0,64$ & 6,45 & \multirow{8}{*}{1,99} \\
\hline $\begin{array}{l}\text { Особисті стосунки / сім'я / } \\
\text { діти }\end{array}$ & $3,68 \pm 0,75$ & $6,27 \pm 0,93$ & 4,05 & \\
\hline Особистісне зростання & $2,71 \pm 0,58$ & $4,43 \pm 0,48$ & 4,81 & \\
\hline $\begin{array}{l}\text { Кар'єра / бізнес / фінанси/ } \\
\text { самореалізація }\end{array}$ & $2,76 \pm 0,78$ & $5,1 \pm 0,76$ & 3,93 & \\
\hline Оточення / друзі & $4,33 \pm 0,97$ & $6,85 \pm 0,84$ & 2,73 & \\
\hline Відпочинок, враження & $2,89 \pm 0,8$ & $5,24 \pm 0,65$ & 4,21 & \\
\hline Творчість / хобі & $2,1 \pm 0,78$ & $5,06 \pm 0,77$ & 7,5 & \\
\hline Духовність & $3,45 \pm 0,73$ & $6,42 \pm 1,43$ & 1,99 & \\
\hline \multicolumn{5}{|c|}{ Військовослужбовці, які займаються футболом (N = 57) } \\
\hline Здоров’я і спорт & $2,28 \pm 0,58$ & $4,59 \pm 0,69$ & 9,35 & \multirow{8}{*}{1,98} \\
\hline $\begin{array}{l}\text { Особисті стосунки / сім'я / } \\
\text { діти }\end{array}$ & $3,73 \pm 0,73$ & $6,21 \pm 0,89$ & 16,27 & \\
\hline Особистісне зростання & $2,68 \pm 0,55$ & $4,35 \pm 0,45$ & 7,74 & \\
\hline $\begin{array}{l}\text { Кар'єра / бізнес / фінанси/ } \\
\text { самореалізація }\end{array}$ & $2,71 \pm 0,78$ & $4,95 \pm 0,75$ & 5,63 & \\
\hline Оточення / друзі & $4,38 \pm 0,93$ & $6,72 \pm 0,87$ & 3,87 & \\
\hline Відпочинок, враження & $2,83 \pm 0,81$ & $5,23 \pm 0,67$ & 17,24 & \\
\hline Творчість / хобі & $2,11 \pm 0,77$ & $5,10 \pm 0,73$ & 1,28 & \\
\hline Духовність & $3,48 \pm 0,71$ & $6,41 \pm 1,26$ & 5,3 & \\
\hline
\end{tabular}

Примітка: наявність достовірних відмінностей за критерієм Стьюденту фіксується при t роз. $>t$ гр. 
B дослідження нами використовувалась сучасна педагогічна SMARTтехнологія «Колесо життєвого балансу» (табл. 2), яка дозволила нам розподілити всі критерії за середніми значеннями кожного з них та визначити ті, якими найбільш за все незадоволені військовослужбовці із наслідками БТ на початку роботи, а саме: найбільш значущими та важливими критеріями для військових із наслідками БТ, які отримують ФСП в секціях 3 футболу $\epsilon$ «особисті стосунки, родина та діти», «особистісне зростання», «духовність» та «оточення, друзі». Критеріями, якими вони найменш задоволені в житті на початок дослідження зафіксовано такі як «творчість/хобі», «особистісне зростання», «здоров’я і спорт» та «відпочинок, враження». Аналіз результатів на кінець дослідження дозволив констатувати наступний розподіл середніх значень за критеріями задоволеності життям, а саме: для військових, які займаються в секціях адаптивного футболу та регбі найбільш важливими $\epsilon$ такі критерії як «оточення та друзі», «духовність» та «особисті стосунки, родина та діти»; критеріями, якими вони найменш за все задоволені $є$ такі критерії «здоров'я і спорт» та «особистісне зростання».

Отже, завдяки використанню технології «Колесо життєвого балансу» ми отримали змогу стверджувати, що найбільш значущими та фундаментальними в своєму житті військові із наслідками БТ вважають такі критерії як «оточення та друзі», «духовність» та «особисті стосунки, родина та діти», тоді як найменш за все вони задоволені такими показниками як «здоров'я і спорт» та «особистісне зростання».

О.А. Орловська [10, с. 102] наголошує на тому, що «перебування в зоні бойових дій супроводжується сильним психотравмуючим впливом через екстремальні ситуації, в які потрапляє учасник бойових дій, що неминуче впливає на психологічний стан, в тому числі й після повернення до цивільного життя. Авторка констатує, що військові - учасники бойових дій переживають морально-психологічні, фізичні навантаження, що руйнують звичне сприйняття, змінюють їх поведінку [10, с. 102]. Дослідниця [10, с. 101] зазначає, що зважаючи на те, що «процес адаптації учасників бойових дій до життєдіяльності в мирних умовах має складний характер, то військовослужбовці потребують особистісної та психо-емоційної підтримки - в такому разі сім'я $є$ вагомим ресурсом в психологічній адаптації. Ми можемо додати, на підставі отриманих даних в ході дослідження, що військові із наслідками БТ розглядають родину і близьких друзів також і як вагомий ресурс фізичної адаптації, в якому вони спираються на їх підтримку, розуміння, фізичну допомогу.

Отримані кількісні та якісні позитивні результати за всіма проведеними тестовими технологіями дозволяють надати рекомендації продовжувати заняття обраними видами спортивних ігор в режимі 3-4 рази на тижні з фізичними навантаженням не менше 60 хв.

Висновки та перспективи подальших досліджень: на підставі отриманих даних можемо зазначити що надання фізкультурно-спортивних послуг учасникам бойових дій із використанням засобів спортивних ігор, зокрема регбі та футболу, сприяє кількісній та якісній зміні показників прояву 
депресивних станів (за методикою PHQ-9), ПТСР, підвищує рівень стресостійкості; за показниками рівня задоволеністю життям (SMARTтехнологія за свідченням учасників $є$ дуже корисною: сприяє вихованню самодисципліни, привчає відповідальності перед самим собою, вчить цінувати час, можливості та бачити шляхи для покращення різних життєвих ситуацій). Вбачаємо необхідність подальших досліджень щодо корекції рівня стресостійкості та подолання наслідків бойової травми у учасників ATO/OOC iз використанням як традиційних, так і інноваційних ФКіС, зокрема спортивних ігор із більш широким колом учасників, включаючи і жінок-ветеранок, а також ще більшим чином розширити віковий діапазон учасників досліджень.

Подяки. Щиру подяку висловлюємо В. Свириденко та К. Винниченко (очільникам Національної ради спортивної реабілітації захисників України) за надання грунтовних консультацій та інформаційну підтримку в ході проведення дослідження та плідну співпрацю.

\section{Лiтература:}

1. Акименко Ю.Ф. Як допомогти родині учасника бойових дій : [методичний посібник для соціальних працівників і психологів] / Ю.Ф. Акименко, Т.І. Сила. Чернігів : Десна Поліграф, 2017. 144 с.

2. Актуальні питання фізкультурно-спортивної реабілітації учасників військових локальних конфліктів в Україні. Юденко О.В., Крушинська Н.М., Юденко Ю.М. Science - the Future of The World. Abstracts of the 5th International scientific and practical conference. Portal Publishing. Prague, Czech Republic. 2020. Pp. 170-176. URL : http://el-conf.com.ua/.

3. Бриндіков Ю.Л. Теорія та практика реабілітації військовослужбовців-учасників бойових дій в системі соціальних служб : дис. ... доктора пед. наук : 13.00.05 / Бриндіков Юрій Леонідович. Тернопіль, 2019. 559 с.

4. Готовність студентів-бакалаврату до участі у фізкультурно-спортивній реабілітації з використанням засобів футболу [Електронний ресурс] / Д.С. Бабенко, О.В. Юденко, С.В. Бойченко. Теоретико-методичні аспекти фізичної культури $і$ спорту : Матеріали науково-практичної конферениії з міжнародною участю. Київ: НУФВСУ. 2020. URL : https://uni-sport.edu.ua/sites/default/files/vseDocumenti/materialy_konferentsiyi__ivanofrankivsk-kyyiv_28.05.2020.pdf.

5. Готовність фахівців спеціальності 017 «Фізична культура i спорт» до використання засобів регбі в системі фізкультурно-спортивної реабілітації учасників бойових дій в Україні. О. Юденко, А. Мартиросян, О. Петрачков, А. Білоус. Військова освіта. 2020. Том 42. Номер 2. C. 363-377. URL: http://znp-vo.nuou.org.ua/article/view/216021

6. Закон України «Про фізичну культуру і спорт» (документ 3808-XII, чинний, поточна редакція - редакція від 01.01.2021, підстава - 645-IX, 910-IX). URL : https://zakon.rada.gov.ua/laws/show/3808-12\#Text

7. Інноваційні засоби фізичної терапії та фізкультурно-спортивної реабілітації військових із дисфункціями в колінному суглобі внаслідок бойової травми. / О. Курбасов, О. Юденко, Н. Крушинська. Abstracts of IX International Scientific and Practical Conference Stockholm, Sweden. 2020. Pp. 166-173. URL : https://sci-conf.com.ua/ix-mezhdunarodnayanauchno-prakticheskaya-konferentsiya-modern-science-problems-and-innovations-15-17-noyabrya2020-goda-stokgolm-shvetsiya-arhiv/.

8. Катунін А.П. Стресостійкість як психологічний феномен / А.П. Катунін. Молодий вчений. 2012. №9. С. 243-246.

9. Кучеренко С. М. Організаційні особливості соціально-психологічної адаптації військовослужбовців, які брали участь у бойових діях, до умов мирного життя. 
С.М. Кучеренко, Н.М. Хоменко. Проблеми екстремальної та кризової психології. Збірник наукових праць. 2017. Вип. 21. С. 66-74.

10. Орловська О.А. Психологічні чинники сімейної адаптації учасників бойових дій. Актуальні проблеми психології. Том I. Випуск 54. C.100-105. URL : http://appsychology.org.ua/data/jrn/v1/i54/17.pdf

11. Показники задоволеністю якістю життя у ветеранів АТО/ООС, 3 наслідками бойової травми, які займаються спортивними іграми. / О.В. Юденко, С.О. Шапіро, Ю.М. Юденко European scientific discussions. Abstracts of the 1st International scientific and practical conference. Potere della ragione Editore. Rome, Italy. 2020. C. 456-466.

12. Психологічна допомога учасникам АТО та їх сім'ям : колективна монографія / M.I. Мушкевич, Р.П. Федоренко, А.П. Мельник [та ін.] ; за заг. ред. М. І. Мушкевич. Луцьк : Вежа-Друк, 2016. 260 с.

13. Сучасні аспекти розвитку фізкультурно-спортивної реабілітації учасників військових локальних конфліктів 3 наслідками бойової травми. / О.В. Юденко, С.М. Жембровський. Сучасні тенденції та перспективи розвитку фізичної підготовки та спорту Збройних Сил України, правоохоронних органів, рятувальних та інших спеціальних служб на шляху євроатлантичної інтеграції України: тези IV Міжнародної науковопрактичної конференції (Київ, 19 листопада 2020 р.) Національний університет оборони України імені Івана Черняховського. Київ : НУОУ, 2020. С. 312-315. URL : https://www.researchgate.net/profile/Iryna_Skrypchenko/publication/348154899_Vikoristanna_stra jkbolu_v_pidgotovci_majbutnih_pravoohoronciv_u_specializovanih_ZVO/links/5ff0d86d299bf140 $886865 \mathrm{fc} /$ Vikoristanna-strajkbolu-v-pidgotovci-majbutnih-pravoohoronciv-u-specializovanihZVO.pdf\#page $=312$

14. Сыропятов О.Г. Медико-психологическое сопровождение специальных операций. / О.Г. Сыропятов. Київ: О.Т. Ростунов, 2013. 292 с.

15. Титаренко Т.М. Технології відновлення психологічного здоров'я особистості в умовах війни: комплексний підхід. 2019. Наукові студії із соціальної та політичної психологіï. URL : https://www.academia.edu/40462954

16. Чапляк А. П. Основні напрямки реабілітації учасників бойових дій / А.П. Чапляк, О.П. Романів, Б.А. Надь. Україна. Здоров’я нащії. 2018. №3/1 (51). С. 59-61.

17. Ягупов В.В. Військова психологія / В.В. Ягупов. Київ: Тандем, 2004. 656 с.

18. Regbi-Militari: в Києві ветерани АTO/OОС змагалися 3 поліцейськими та британськими інструкторами «Орбітал». URL : http://pivnich.org.ua/678-regbimilitari-v-kyieviveterany-atooos-zmagalysia-z-policeiskymy-ta-brytanskymy-instruktoramy-orbital.html

19. Belmont Ph.J., McCriskin B.J., Sieg R.N. Combat wounds in Iraq and Afghanistan from 2005 to 2009. J. Trauma Acute Care Surg. 2012; 73: 3-12.

20. Forensic Medicine of the Lower Extremity [Electronic resource] / ed. J. Rich, D.E. Dean, R.H. Powers. Totowa : Humana Press, 2005; 421.

21. Knapik J.J., Jones S.B., Darakjy S. et al. Injury rates and injury risk factors among U.S. Army wheel vehicle mechanics. Mil. Med. 2007; 172(9): 988-996.

22. Marin R. Physical medicine and rehabilitation in the military: Operation Iraqi Freedom. Mil. Med. 2006, Mar.; 171(3): 185-188.

23. Owens B.D., Kragh J.F., Wenke J.C. Combat Wounds in Operation Iraqi Freedom and Operation Enduring Freedom. J. Trauma. 2008; 64: 295-299.

24. Postmilitary Adjustment to Civilian Life: Potential Risks and Protective Factors. / Mary Beth MacLean, Linda Van Til, James M. Thompson, Jill Sweet, Alain Poirier, Kerry Sudom, David J. Pedlar. Physical Therapy. Vol. 94. № 8. August 2014. Pp. 1186-1195. URL : https://watermark.silverchair.com/ptj1186.pdf

25. Rehabilitation programs for musculoskeletal injuries in military personnel. / Kathleen E Yancosek 1, Tanja Roy, Mary Erickson 2012 Mar;24(2):232-6. (DOI: 10.1097/BOR.0b013e3283503406) URL : https://pubmed.ncbi.nlm.nih.gov/22249351/ 
26. Rehabilitation through adapted sports: The French military way. / S. Truffaut, M. Thomas-Pohl, L. Borrini, D. Rogez, J. Facione, E. Lapeyre. Annals of Physical and Rehabilitation Medicine. Vol. 61, Supplement, July 2018, Page e76. (https://doi.org/10.1016/j.rehab.2018.05.164). URL : https://www.sciencedirect.com/science/article/pii/S1877065718302380?via\%3Dihub

27. Williams, C. M. Family Therapy of Vietnam Veterans. The Trauma of War // C. M. Williams, T. Williams // ed. S.Sonnenberg, A. Blank, J. Tallbot. In the trauma of far: stress and recovery in the Viet Nam veterans. Washington : American Psychiatric Press, 1985. P. 193209.

\section{РЕЗЮМЕ}

Оксана Юденко, кандидат педагогических наук, доцент кафедры профессионального, неолимпийского и адаптивного спорта Национального университета физического воспитания и спорта Украины

Василий Белошицкий, начальник научно-исследовательской лаборатории научного сопровождения разработки нормативов и стандартов физической подготовки и спорта, подполковник Учебно-научного института физической культуры и спортивно-оздоровительных технологий Национального университета обороны Украины имени Ивана Черняховского

Сергей Бойченко старший преподаватель кафедры футбола Национальный университет физического воспитания и спорта Украины Генадий Галашевский старший преподаватель кафедры физического воспитания, специальной физической подготовки и спорта, подполковник Учебно-научный институт физической культуры и спортивно-оздоровительных технологий Национальный университет обороны Украины, г. Киев

\section{Коррекция стрессоустойчивост средствами спортивных игр у военнослужащих с последствиями боевой травмы}

Актуальность работь заключается в том, что когда в 2014 году против Украиньл были начаты военные действия на востоке страны количество лиц, нуждаюшихся $в$ качественных, эффективных, своевременных коррекционно-реабилитационных вмешательствах постоянно растет. На сегодня количество человек официально зарегистрированных как участники боевых действий достигла более 500000 человек, но при этом лишь только более 40000 травмированных военных с различнылми последствиями боевой травмы получили необходимые реабилитационные и физкультурно-спортивные услуги.

Ключевые слова: футбол, регби, физкультурно-спортивная реабилитация, боевой стресс, коррекиионно-реабилитациионное влияние, участники АТО/OОС.

\section{SUMMARY}

Yudenko Oksana,

Candidate of Pdagogical Sciences, Associate Professor of the

Department of Professional, Non-Olympic and Adaptive Sports of the National University of Physical Education and Sport of Ukraine

Vasyl Biloshytskyi

head of the research laboratory of scientific support development of norms and standards of physical training and sports, lieutenant colonel Educational and Scientific Institute of Physical Culture and Sports and Health Technologies Ivan Chernyakhovsky National University of Defense of Ukraine 
Sergei Boychenko

senior teacher of the football department National University of Physical Education and Sport of Ukraine

Gennady Galashevsky senior lecturer of the Department of physical education, special physical training and sports, lieutenant colonel Educational and Scientific Institute of Physical Culture and Sports and Health Technologies Ivan Chernyakhovsky National University of Defense of Ukraine

\section{Correction of stress resistance by means of sports games soldiers with consequences of combat injury}

The urgency of the work is that since 2014, when hostilities were launched against Ukraine in the east of the country, the number of people in need of quality, effective, timely correctional and rehabilitation intervention is constantly growing. To date, the number of people officially registered as combatants has reached more than 500,000, but only more than 40,000 injured soldiers with various consequences of combat injuries have received the necessary rehabilitation and sports services.

Purpose: assessment of the degree of stress resistance in the military with the consequences of BT and its correction by means of sports games.

Research methods: a) analysis and generalization of scientific-methodical and electronic information sources; b) rapid assessment of PTSD; c) self-assessment of health in the military "PHQ-9» (self-assessment of depression); d) modern pedagogical SMART-technology "Wheel of life balance»; e) methods of mathematical statistics (Student's criterion).

Presentation of the main research material. Stress resistance is a «set of personal qualities that allow you to transfer significant intellectual, volitional and emotional loads without particularly harmful consequences for their own health, others and their professional activities», and physical rehabilitation is interpreted as a system of measures developed using physical exercises to restore a person's health and aimed at recovery and compensation through physical education and sports.

The study during 2019-2020 took 42 servicemen with the consequences of combat injury engaged in adaptive rugby, 57 people engaged in adaptive football.

Conclusions and prospects for further research: we can note that the provision of physical culture and sports services to combatants using sports, including rugby and football, contributes to quantitative and qualitative changes in the incidence of depression (PHQ-9), PTSD, increases stress resistance; according to the indicators of the level of life satisfaction (SMART-technology according to the participants is very useful: it promotes self-discipline, teaches responsibility to oneself, teaches to value time, opportunities and see ways to improve different life situations).

Key words: football, rugby, physical culture and sports rehabilitation, combat stress, corrective-rehabilitation influence, participants of Anti-Terrorist Operation / Joint Forces Operation. 